\title{
Civil law regulation of town planning
}

\author{
Elena Voskresenskaya ${ }^{1,{ }^{*}}$, Nikolay Zhilskiy ${ }^{1}$, Nicolay Golovanov $^{1}$, and Natalya Pisareva ${ }^{1}$ \\ ${ }^{1}$ Saint Petersburg State University of Architecture and Civil Engineering, 190005, St. Petersburg, 2nd \\ Krasnoarmeyskaya St., 4, Russia
}

\begin{abstract}
The present research article contains the legal analysis of prescription of the procedure and levels of law making in the field of civil and town planning legislation. The authors have explored their nature and origin, which will help fill the gaps in legislation and eliminate the existing conflicts of law. The current town planning legislation is of complex nature, so it cannot be applied without taking into account civil law, which directly influences town planning relations. It is worth mentioning that both town planning and civil law relations depend on the set of other constitutional principles related to the right of ownership, right of undertaking entrepreneurial or other economic activities, intellectual property right, etc. Interrelation and differentiation of regulations of town planning and civil legislation are currently essential. Civil legislation is manifested mainly by the Civil Code of the Russian Federation, which regulates property and some non-property yet associated relations that concern town planning activities. For the last years, the Russian legislation has paid much attention to statutory regulation of town planning relations, passing the way from federal laws to codification. The present paper focuses on the social and economic role of town planning and its place in current times.
\end{abstract}

\section{Introduction}

The authors of the article have investigated civil law relations in the area of town planning and statutory regulations aimed at prescription of urban relations. Based on statistics, the authors pursued the comprehensive research and analysis of the impact of civil law on urban relations. The article gives the concept of town planning relations and their interrelation with the subject of civil law regulation. The study of the place of civil statutory regulations in the system of town planning legislation and the improvement of the nomenclature will contribute to the successful implementation of the town planning policy of the government aimed at the sustainable socio-economic development of cities and the improvement of property relations in the field of housing development.

The problems of interaction and differentiation of regulations regarding town planning and other branches of legislation are considered in certain works of the researchers [1-8].

However, these works do not contain the comprehensive analysis of the influence of civil law regulations on the legal control over property relations in the field of town planning. The authors focused on some certain legal aspects of town planning [9-12].

\footnotetext{
${ }^{*}$ Corresponding author: elenvoskr@mail.ru
} 
Therefore, public law prerequisites, due to the initial demand for licensing procedures of a public nature, require a legal analysis of general and distinctive features in order to improve the mechanisms of legal control.

\section{Materials and Methods}

The methodological basis of the study is the systematic approach that is necessary for studying the correlation of civil and town planning legislation. The article uses a set of scientific cognition methods, including concrete-historical, system-functional, formal legal, comparative legal, logical and other approaches, as well as general theoretical provisions of the civil law theory.

The following regulatory legal acts prescribing town planning activities serve as the regulatory framework of the study: The Constitution of the Russian Federation, the Civil Code of the Russian Federation, the Town-Planning Code of the Russian Federation and other federal laws and regulations.

The study is aimed at the comprehensive and systematic study of the problems of property turnover in the field town planning, the substantiation of the socio-economic importance of town planning, the study of the concept of town planning relations and their interrelation with the subject of civil law regulation.

\section{Results}

Construction is one of the most significant industries, since its development leads to the economic growth of the state. Construction statistics show the state and development level of the sector. Data analysis allows tracking the dynamics by years and make forecasts. In 2017, construction statistics in the Russian Federation recorded 7545.94 billion rubles as the volume of work performed, which is $4.75 \%$ higher than in 2016 (tables 1 and 2) [13]. The volumes of commissioning of residential, non-residential (Figure 1) and other (Figure 2) buildings in Russia for 2015-2017 are given in tables 3, 4 and 5 [14].

The indicators increased in 40 regions. Almost $58 \%$ of the total volume of construction work accounts for the Central, North-West and Volga Regions. Construction statistics in Russia recorded the highest growth rates in the Republic of Crimea, Sakha, Ingushetia. In 45 constituent entities of the Russian Federation, the volume of housing development decreased. The worst performance was shown by Kalmykia. There, the volume of construction works decreased by $67.4 \%$.

Table 1. The volume of work performed by type of economic activity "Construction".

\begin{tabular}{|c|c|c|c|}
\hline & 2015 & 2016 & 2017 \\
\hline Mln. roubles (at current prices) & 7010356 & 7204235 & 7545912 \\
\hline Percent of previous (at constant prices) & 96.1 & 97.8 & 98.6 \\
\hline
\end{tabular}


Table 2. The volume of work performed by type of economic activity "Construction" by ownership.

\begin{tabular}{|l|c|c|c|}
\hline & 2015 & 2016 & 2017 \\
\hline Total & Mln. roubles & & \\
\hline $\begin{array}{l}\text { including by ownership types of } \\
\text { organizations: }\end{array}$ & $\mathbf{7 0 1 0 3 5 6}$ & $\mathbf{7 2 0 4 2 3 5}$ & $\mathbf{7 5 4 5 9 1 2}$ \\
\hline state & & & \\
\hline municipal & 157606 & 153865 & 132927 \\
\hline private & 17197 & 18526 & 16477 \\
\hline mixed Russian & 6403224 & 6518971 & 8909652 \\
\hline other & 92614 & 65169 & 58966 \\
\hline & 339715 & 447702 & 427890 \\
\hline Total & $\mathbf{1 0 0}$ & & \\
\hline $\begin{array}{l}\text { including by ownership types of } \\
\text { organizations: }\end{array}$ & & $\mathbf{1 0 0}$ & $\mathbf{1 0 0}$ \\
\hline state & 2.2 & & \\
\hline municipal & 0.2 & 2.1 & 1.8 \\
\hline private & 91.4 & 0.3 & 0.2 \\
\hline mixed Russian & 1.3 & 90.5 & 91.6 \\
\hline other & 4.9 & 0.9 & 0.8 \\
\hline
\end{tabular}

Table 3. Commissioning of residential buildings.

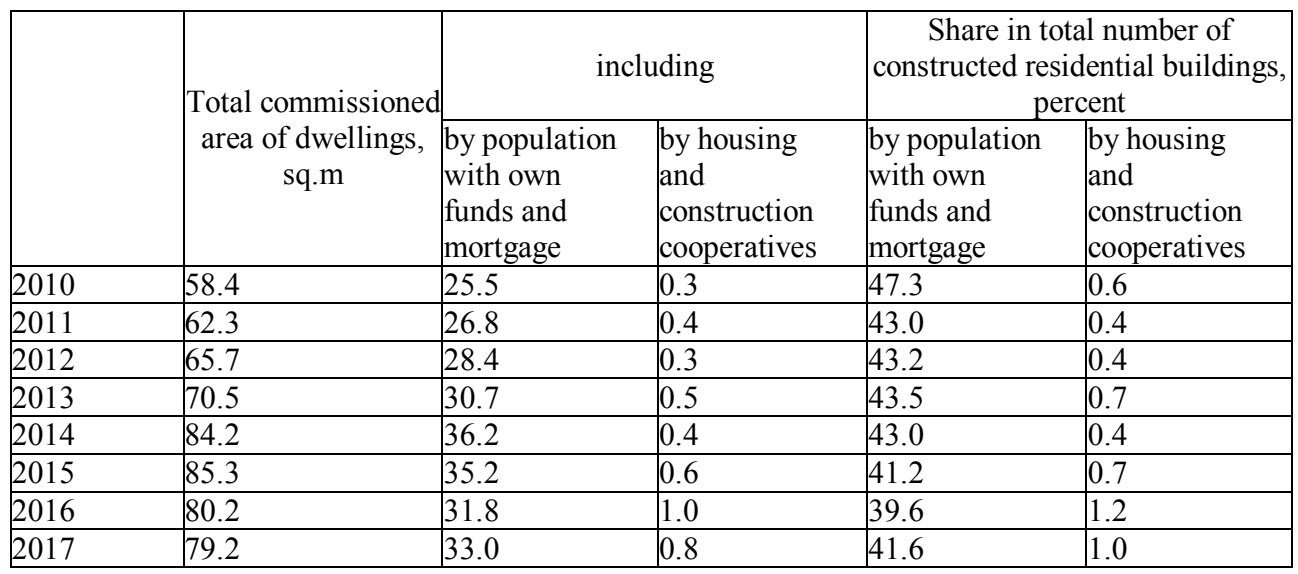

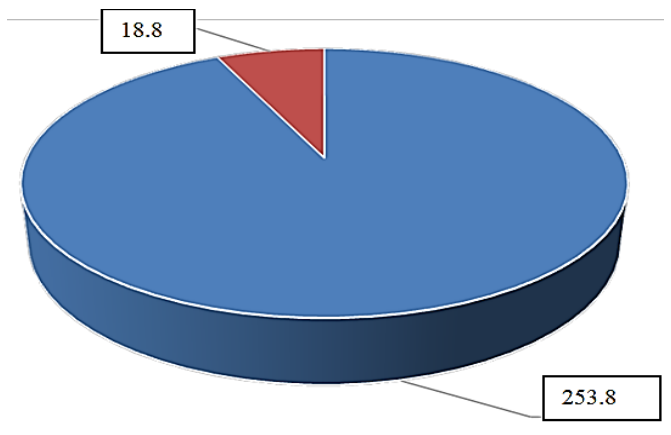

- Residential - Nonresidential

Fig. 1. Commissioning of buildings, total thou. 
Table 4. Commissioning of buildings.

\begin{tabular}{|c|c|c|c|}
\hline & 2015 & 2016 & 2017 \\
\hline Buildings - total, thou. & 306.4 & 278.3 & 272.6 \\
\hline \multicolumn{4}{|l|}{ including: } \\
\hline residential & 286.1 & 259.5 & 253.8 \\
\hline nonresidential & 20.3 & 18.8 & 18.8 \\
\hline \multicolumn{4}{|l|}{ of which: } \\
\hline industrial & 3.1 & 2.9 & 2.7 \\
\hline agricultural & 2.5 & 2.7 & 2.7 \\
\hline commercial & 7.2 & 6.1 & 6.3 \\
\hline administrative & 1.3 & 1.2 & 1.2 \\
\hline education & 1.2 & 0.7 & 0.6 \\
\hline health-care sector & 0.8 & 0.7 & 0.6 \\
\hline other & 4.2 & 4.5 & 4.7 \\
\hline $\begin{array}{l}\text { Total volume of buildings - total, min. cu. } \\
\text { m }\end{array}$ & 622.8 & 608.5 & 599.4 \\
\hline \multicolumn{4}{|l|}{ including: } \\
\hline residential & 415.7 & 400.4 & 401.3 \\
\hline nonresidential & 207.1 & 208.1 & 198.1 \\
\hline \multicolumn{4}{|l|}{ of which: } \\
\hline industrial & 48.8 & 45.5 & 46.3 \\
\hline agricultural & 27.3 & 34.7 & 42.0 \\
\hline commercial & 72.0 & 65.4 & 53.3 \\
\hline administrative & 10.0 & 9.6 & 7.6 \\
\hline education & 19.5 & 14.8 & 15.6 \\
\hline health-care sector & 4.0 & 4.7 & 4.7 \\
\hline other & 25.5 & 33.4 & 28.6 \\
\hline Total area of buildings - total, min. cu. m & 139.4 & 135.8 & $\mathbf{1 3 7 . 3}$ \\
\hline \multicolumn{4}{|l|}{ including: } \\
\hline residential & 106.2 & 103.4 & 104.6 \\
\hline nonresidential & $33 . .2$ & 32.4 & 32.7 \\
\hline \multicolumn{4}{|l|}{ of which: } \\
\hline industrial & 4.8 & 4.6 & 4.8 \\
\hline agricultural & 5.1 & 5.8 & 7.7 \\
\hline commercial & 11.6 & 10.2 & 9.0 \\
\hline administrative & 2.1 & 1.9 & 1.6 \\
\hline education & 4.5 & 3.3 & 3.3 \\
\hline health-care sector & 0.9 & 1.1 & 1.3 \\
\hline other & 4.2 & 5.5 & 5.0 \\
\hline
\end{tabular}

In 2017, 79.2 million square meters of housing were commissioned in the Russian Federation, which is $2.1 \%$ less than in 2016. Statistics on the construction of residentialbuildings show that the share of individual developers in the total volume was $41.6 \%$, who erected 241.1 thousand residential buildings with a total area of 32.7 million square meters. The increase was $2.8 \%$. Construction statistics show that over the past 14 years, the volume of individual housing construction has been annually increasing, with the exception of a slight indicator drop in 2010-2011. 
Table 5. Commissioning of residential buildings in cities, urban-type settlements and rural area.

\begin{tabular}{|c|c|c|c|}
\hline & 2015 & 2016 & 2017 \\
\hline \multicolumn{4}{|c|}{ Total area of dwellings, sq. $\mathrm{m}$} \\
\hline In urban area & 62.0 & 58.8 & 57.2 \\
\hline In rural area & 23.3 & 21.4 & 22.0 \\
\hline \multicolumn{4}{|c|}{ Built by population with own funds and mortgage } \\
\hline in urban area & 16.3 & 14.9 & 15.5 \\
\hline in rural area & 18.9 & 16.9 & 17.5 \\
\hline \multicolumn{4}{|c|}{ Total area of dwellings per 1000 population, sq. $\mathrm{m}$} \\
\hline $\begin{array}{l}\text { In urban area and rural } \\
\text { area }\end{array}$ & 583 & 547 & 540 \\
\hline In urban area & 571 & 541 & 523 \\
\hline in rural area & 616 & 586 & 585 \\
\hline
\end{tabular}
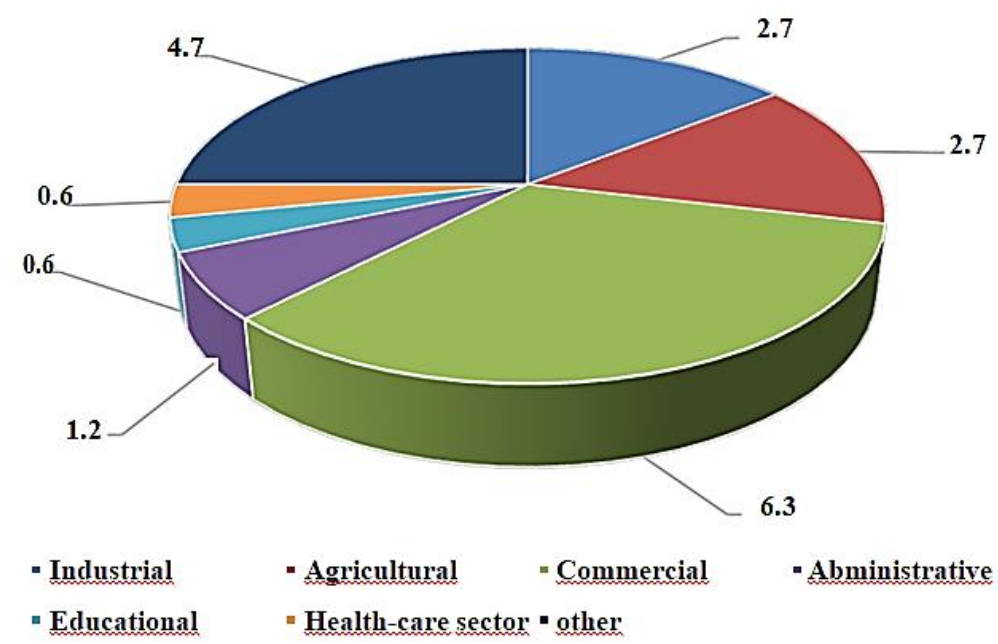

Fig. 2. Nonresidential buildings, total thou.

According to the statistics of housing construction the Moscow Region ranks first. $11.2 \%$ of the total volume of apartments built accounts for the Moscow Region, then $5.9 \%$ for Krasnodar Krai, 4.5\%. for St. Petersburg, 4.4\% for Moscow. According to the statistics the volume of housing construction decreased in the Novosibirsk region by $22.1 \%$, in the Republic of Bashkortostan by $8.8 \%$, and in the Samara region by $6.8 \%$.

Statistics of housing construction shows that over the past five years, the largest increase in commissioned housing was in $2014(+18.2 \%)$. However, since 2016, there has been a decrease in the indicator $(-6 \%)$.

The main goal of the Town Planning Code of the Russian Federation (hereinafter - the TPC of the RF) [10] is the legal regulation of people resettlement, urban planning, housing development, improvement of settlements, development of their infrastructure, rational nature management, ensuring favorable living conditions for the population. According to the current TPC of the RF, the concepts of "town planning" and "town planning activity" have different meanings.

Town planning activity refers to the development of territories, including cities or other settlements, which is carried out in the form of land use planning, urban zoning, territory 
planning, architectural design, construction, overhaul, reconstruction of capital construction objects (Clause 1, Article 1 of the TPC of the RF).

Town planning is considered as the result of town planning activity. The special purpose of town planning activity is the development of town planning as a specific sector of the economy that is highly demanded by the society. Its functioning is possible through the systematic organization of specific manufactural relations concerning the development of cities and settlements.

The analysis allowed making a conclusion that town planning takes the following place and plays the following socio-economic role:

- it contributes to the reasoned resettlement of the population and creation of the necessary engineering, transport and social infrastructure (Clause 4, Article 24 and others of the TPC of the RF);

- creates the conditions for the realization by each citizen of the rights to a favorable living environment, providing the opportunity to exist, move, work and relax freely and without damage to health (Clause 6, Clause 2, Clause 39 Clause 1; Clause 28 Clause 1;.5 Art. 35, Clause 7, Art. 46 of the TPC of the RF);

- provides the most efficient use of natural resources (paragraph 3 of article 1, paragraph 9 of article 2, paragraph 4 of article 47 of the TPC of RF).

Statistics in the construction sector in 2017 totaled 279.5 thousand enterprises. The share of small business is 235.5 thousand (tables 6 and 7) [12].

Table 6. Construction organizations.

\begin{tabular}{|l|c|c|c|}
\hline & 2015 & 2016 & 2017 \\
\hline $\begin{array}{c}\text { Construction } \\
\text { organizations - } \\
\text { total }\end{array}$ & 232154 & 271604 & 279496 \\
\hline $\begin{array}{l}\text { including small } \\
\text { businesses (with } \\
\text { micro- } \\
\text { enterprises) }\end{array}$ & 224255 & 262129 & 262403 \\
\hline $\begin{array}{l}\text { of which micro- } \\
\text { enterprises }\end{array}$ & 194645 & 240709 & 235496 \\
\hline
\end{tabular}

Table 7. Construction organizations by type ownership.

\begin{tabular}{|l|r|r|r|}
\hline \multicolumn{2}{|c|}{2015} & \multicolumn{1}{c|}{2016} & \multicolumn{1}{|c|}{2017} \\
\hline \multicolumn{3}{|c|}{ Construction organizations } \\
\hline Buildings - total, thou. & 232154 & 271604 & 279496 \\
\hline state & 832 & 776 & 759 \\
\hline municipal & 461 & 426 & 442 \\
\hline private & 229943 & 269548 & 276944 \\
\hline mixed Russian & 293 & 242 & 283 \\
\hline other & 625 & 610 & 1068 \\
\hline \multicolumn{2}{|c|}{ Percent of total } & \\
\hline $\begin{array}{l}\text { Total area of buildings - total, } \\
\text { min. cu. m }\end{array}$ & 100 & 100 & 100 \\
\hline state & 0.4 & 0.3 & 0.3 \\
\hline municipal & 0.2 & 0.2 & 0.2 \\
\hline private & 99.0 & 99.2 & 99.1 \\
\hline mixed Russian & 0.1 & 0.1 & 0.1 \\
\hline other & 0.3 & 0.2 & 0.3 \\
\hline
\end{tabular}


In 2017, the volume of investments in the housing sector amounted to 225 billion rubles. Their share in the total volume of investments in fixed assets amounted to $15.4 \%$ (table 8) [12].

Table 8. Investments in fixed capital of construction organizations

\begin{tabular}{|c|c|c|c|}
\hline & 2015 & 2016 & 2017 \\
\hline Bln. roubles (at current prices) & 919.8 & 877.0 & 870.8 \\
\hline Percent of total volume investments & 8.8 & 7.8 & 7.1 \\
\hline
\end{tabular}

In recent years, the government has been promoting low-rise construction. According to statistics, the share of low-rise housing has grown to $52 \%$ over 10 years. The increase amounted 14\%. This segment is one of the most promising directions in Russia. According to forecasts, its share in total housing will reach $70 \%$ by 2020 . In Russia, about $80 \%$ of new buildings are funded by shared-equity construction participants. According to statistics, for the 3rd quarter of 2017, about 1.1 million shared-equity agreements were registered in the country.

Construction statistics in Moscow recorded a peak number of shared-equity contracts. In 2017, 55.2 thousand agreements were made, which was 52\% more than in 2016. Just in December, the number of registered agreements equaled 6689 . The graph shows the growth rate of the concluded shared-equity agreements.

Statistics of school construction in Russia totals 82 educational institutions in 2017. The number of new school places increased by 55 thousand. In 2018, 131.6 thousand school places were created. Approximately 89.3 billion rubles will be allocated from the federal budget for the erection of schools.

In 2017, the costs of construction, reconstruction and repair of roads amounted to 360 billion rubles. Over 209.8 thousand roads were built and reconstructed. The total length of roads in Russia by 2016 approximately amounted to 1.49 million km. $50.7 \mathrm{~km}$ accounts for Moscow. At the beginning of 2017, the length of federal roads was 49.7 thousand $\mathrm{km}$. By the end of the year, this indicator increased to 50.1 thousand $\mathrm{km}$. During 2017, statistics of road construction recorded the increase equaling more than $400 \mathrm{~km}$. 65.9 billion rubles were allocated for the maintenance of federal highways.

\section{Discussion}

Town planning relations are considered to be specific manufactural relations that are worked out within the town planning activities aimed at the development of cities and settlements. These relations are intended to meet the territorial and town-planning needs and demands of the population and the society.

Town planning relations cover the following types of social relations: land use planning; urban zoning; territory planning; construction of capital facilities; reconstruction of capital facilities. The subject of regulation of town planning legislation is associated with the subject of civil law regulation, which is defined in Art. 2 of the TPC of the RF and implies property and related non-property personal relations based on equality, free will and property independence of the participants.

The analysis allows concluding that the civil law component takes a significant part in the legal regulation of town planning, since in most cases, the subjects of legal regulation of town planning legislation are of a property nature and are based on equality, free will and property independence of their participants. The coincidence of both the objects of rights and the subjects of legal regulation of town planning and civil legislation proclaims the significant role of civil law in the regulation of town planning relations. 


\section{Conclusions}

The authors came to the conclusion that mechanisms of legal regulation of town planning activities should be improved on a constant basis in order to ensure the ongoing socioeconomic development of the society.

The authors proposed their own definition of town planning as a specific field in the economy which is resulted from town planning activities. The functioning of town planning is carried out through the systematic organization of specific town planning relations aimed at developing the territories of cities and settlements, satisfying town planning needs and demands of the population. The necessary legal stability and new development opportunities for town planning relations are provided by the civil law standards and principles. The solution of problems of town planning is possible as long as the system of legal mechanisms for control over town planning relations contains the civil law methods for regulating property relations.

The authors offer the particularized list of law branches (Clause 3, Article 4 of the TPC of the RF), the legislation of which is applicable to town planning relations and should be supplemented by the reference to the civil law.

The theoretical provisions and analysis presented in the paper justify the scientific idea of the need to regulate town planning relations comprehensively, using among other things the rules of private law, and also highlight the influence of civil law structures on the efficiency of town planning activities.

\section{References}

1. O. I. Krassov, Permitted use and competitive target designation of the land plot (2012).

2. Ya. V. Manin, Administrative and legal regulation of the use of Federal subsoil plots within the territory of the Russian Federation (2012).

3. E. V. Marin, Financing of environmental protection of medium and regional nature management: judicial, legal and tax mechanisms (2012).

4. D. O. Sivakov, The Russian Arctic is needed in integrated environmental management (2015)

5. N. Glubeneva, Legal support of economic incentives in the field of environmental protection (2013)

6. S. Scheinfeld, A foreign experience in legal regulation of the provision of land plots for subsurface use (2012)

7. N. M. Ovsyannikov, Innovation management (2011)

8. K. S. Pickowicz, The development of intellectual property: international relations (2012)

9. E. Voskresenskaya, L. Vorona-Slivinskaya, Y. Tilinin, VE3s Web of Conference 110, 02068, (2019) https://doi.org/10.1051/e3sconf/201911002068

10. E. Voskresenskaya, L. Vorona-Slivinskaya, D. Mokhorov, A. Tebryaev, E3S Web of Conferences 110, 02067, (2019) https://doi.org/10.1051/e3sconf/201911002067

11. E. Voskresenskaya, N. Rilski, E. Sharapova, MATEC WEB of CONFERENCES 170, 01057 (2018) DOI https://doi.org/10.1051/matecconf/201817001057

12. E. Voskresenskaya, L. Vorona-Slivinskaya, T. Ponomareva Matek Web of conferences 193, 01028, (2018) https://doi.org/10.1051/matecconf/201819301028 